\section{International Journal \\ of \\ English Studies}

IJES

http://revistas.um.es/ijes

\title{
The DIVIDED SELF metaphor: A cognitive-linguistic study of two poems by Nabokov ${ }^{1}$
}

\author{
Ma ASUNCIÓN BARRERAS GÓMEZ * \\ Universidad de La Rioja
}

Received: 30/10/2014. Accepted: 17/02/2015.

\begin{abstract}
This paper will approach two of Nabokov's poems from the perspective of embodied realism in Cognitive Linguistics. We will shed light on the reasons why we believe that Nabokov makes use of the DIVIDED SELF metaphor in his poetry. In the analysis of the poems we will explain how the Subject is understood in the author's life in exile whereas the Self is understood in the author's feelings of anguish and longing for his Russian past. Finally, we will also explain how Nabokov's use of the DIVIDED SELF metaphor thematically structures both poems.
\end{abstract}

KEYWORDS: Cognitive Linguistics, DIVIDED SELF metaphor, Subject, Self.

\section{RESUMEN}

Este artículo explicará dos poemas de Nabokov desde la perspectiva de la lingüística cognitiva. Se razonará porqué consideramos que Nabokov utiliza la metáfora del YO DIVIDIDO en su poesía. En el análisis se explicará cómo el sujeto se entiende en la vida del exilio del autor mientras que el ego se aprecia en los sentimientos de angustia y nostalgia por su pasado ruso. Finalmente, también explicaremos cómo el uso de la metáfora del yo DIVIDIDO estructura temáticamente ambos poemas.

PALABRAS CLAVE: Lingüística cognitiva, metáfora del Yo DiVIDIDO, sujeto, ego.

\footnotetext{
*Address for correspondence: María Asunción Barreras Gómez. Departamento de Filologías Modernas, Universidad de la Rioja, C/ San José de Calasanz s/n, 26004 Logroño (La Rioja), Spain; e-mail: asuncion.barreras@unirioja.es
} 


\section{INTRODUCTION}

The present study is based on the main principles of Conceptual Metaphor Theory (CMT), as originally propounded by Lakoff and Johnson (1980, 1999) and Lakoff $(1987,1993)$, within the framework of Cognitive Linguistics (CL). This theory is very well known by now. However, interested readers may find fairly updated critical overviews in Dirven and Ruiz de Mendoza (2010), Gibbs (2011), Kövecses (2011), Ruiz de Mendoza and Pérez (2011), and Steen (2010), among others.

One of the tenets of CMT that has attracted more attention since its inception is the claim that metaphor is essentially a matter of ordinary, everyday thought, rather than just a literary device. In addition, CMT postulates that metaphor is highly pervasive in human reasoning and, as a consequence, in language. This is so because of its nature as a central cognitive process. As such, metaphor consists in mapping, i.e. putting into correspondence, structure from two discrete conceptual domains, one of which, called the source is used to reason and talk about the other, called the target. The source domain is often grounded in everyday experience, whereas the target domain can occur in any degree of abstraction. Expressions such as They are in a dead-end relationship or This relationship isn't going anywhere are examples of the oft-cited metaphor LOVE IS A JOURNEY (Lakoff, 1993), which exploits the idea that love relationships are purposeful activities that can be understood in terms of a traveller's goals of reaching a destination. Thus, a "dead-end relationship" is one that will not allow its participants to make any further progress, while a relationship that "isn't going anywhere" is one that has lost its sense of purpose thereby becoming meaningless.

Analyses of metaphor along the preceding lines are numerous and some metaphorical systems have received a special amount of attention, among them time-space correlations (Casasanto and Boroditsky 2008; Lakoff and Johnson 1999), emotion metaphors (Kövecses, 2000), and motion metaphors (Talmy, 2000). One metaphorical system that has comparably received little attention is the DIVIDED SELF metaphor (Lakoff, 1993). This metaphor reflects the dual rational-emotional nature of human beings. In it, a person (the target) is understood as a physically fragmented human being consisting of the Subject (which houses the rational aspects of the person) and the Self (which houses the bodily and emotional aspects). We use this idea in everyday expressions such as I made myself go to class, I'm not myself today, He is ahead of himself, I'm scattered, Put yourself together, and a host of related expressions. In general, cognitive linguists take for granted that we find the same kind of metaphors both in everyday language use and in literary language. Surprisingly, there is no study so far that takes into account the impact of the divided-self system in literary language. In addition, those cognitive linguists who do explore metaphor in literature, while acknowledging the role of metaphor to endow texts with conceptual and thematic consistency, seem oblivious to the possibility that metaphor is either consciously or unconsciously used by the writer as 
structuring factor. As will be shown in this paper, through a case study of two of Nabokov's poems, the DIVIDED SELF metaphor can be such a structuring factor. This should not be surprising since Nabokov made extensive use in all his non-poetic production of the literary motif known as Doppelgänger, i.e. the double of a living person, which is generally a counterpart of the protagonist's self, as we will discuss later on in this paper. One of the two poems selected for the present case study, Hotel Room, makes full use of this literary motif for specific artistic reasons. The motif in this poem takes the form of the DIVIDED SELF metaphor. In the other, The Execution, the motif is less obvious, but there are subtle indications of its presence. In the Hotel Room the DIVIDED SELF metaphor is pervasive and adopts a structuring role, whereas in The Execution the same metaphor appears at the end of the poem, in the last stanza, as a way of re-construing the emotional and rational experiences that the poet brings up in the previous stanzas. The Execution thus uses the DIVIDED SELF metaphor as a synthesis - by way of conclusion- of previous thematic contrasts.

In order to better substantiate the previous points, we will first give a brief outline of the theory of embodied realism in $\mathrm{CL}$, on which the notion of experientialism is grounded. Embodied realism substantiates the use of the DIVIDED SELF metaphor not only in everyday language use but also, we will argue, in its more literary manifestations. Then, we will offer a brief biography of the poet and address the role of the Doppelgänger in this connection. This will not only allow us to contextualize the content of the two poems that will be the object of our discussion, but will also shed light on the reasons why we believe that Nabokov makes use of the DIVIDED SELF metaphor in his poetry. After that, we will analyse relevant aspects of the two poems from the point of view of CL. Finally, we will provide a summary of conclusions.

\section{SOME BASIC NOTIONS ON EMBODIED REALISM}

Cognitive linguists, following seminal proposals by Lakoff (1987) and Johnson (1987), argue that our thought processes, and consequently language use, is grounded in how we relate to the world in terms of bodily experience. According to Lakoff and Johnson (1999), motorsensory experience is the basis for our conceptual processes and interaction with other people. Consequently, our concepts stem from such cognitive abilities as perception, memory, emotion or reasoning, which allows us to interact with the environment. ${ }^{2}$

We use our experience in order to understand and express abstractions. That is why we commonly use metaphors in our daily life. Lakoff and Johnson provide numerous examples of metaphors in their seminal books Metaphors We Live By (1980) and Philosophy in the Flesh (1999). Many of these metaphors are pervasive in language and thought. An example of a highly recurrent conceptual metaphor is KNOWING IS SEEING, as evidenced by the commonness of expressions such as I see and Can you see? where see is used in the sense of 'understand.' This metaphor is grounded in the fact that visual inspection is one of the best 
sources of information on the world around us: when people see objects they can perceive their visible physical attributes, such as their colour, size and shape and also locate them in terms of space. This allows people to understand and know about such objects. The metaphor KNOWING IS SEEING is thus a matter of sensory motor input, i.e. on how we interact with the world on the basis of our bodily experience. ${ }^{3}$

Since perceptual and motor experience play such a central role in conceptualization, it should not be surprising to find that basic metaphors grounded in experience can be part and parcel of the way writers come to terms with the structure of their messages. To give a straightforward example, think of story schemas (also called story grammars), as first proposed by Rumelhart (1975) and Thorndyke (1977). These schemas were used to structure whole stories in terms of the protagonists' attempts to achieve goals and the various methods employed. There was some controversy as to the status of story schemas as memory or comprehension devices (Rumelhart, 1980), but what these theorists failed to note is that their basic goal-related problem solving pattern was a part of our everyday experience: characters have goals and become involved in actions that serve as attempts to satisfy their goals. The means-goals schema not only underlies our understanding of expressions such as He will pursue his goals with perseverance (where goals are moving objects that one can strive to catch up with), but it also supports more global thinking and is capable of structuring a whole narrative. In a similar way, we can find that other experiential schemas can give overall shape to other cases of meaningful communication like a poem. Our contention in the present study is that this is the case of the DIVIDED SELF metaphor in (at least) two of Nabokov's poems.

\section{COGNITIVE POETICS}

The application of CL to the study of literature has been called Cognitive Poetics. As Tsur (2002: 279) remarks: "[Cognitive Poetics] offers cognitive hypotheses to relate in a systematic way the specific effects of poetry to the particular regularities that occur in literary texts."

Outside CL, there have been some critics who have argued in favor of the importance of combining the linguistic description and the literary appreciation in the analysis of literary texts, such us Steiner (1970) or Leech and Short (1995). In much the same way, Cognitive Poetics lays a bridge between literary studies and linguistics, which is in this case considered more broadly in connection with the human mind. Thus, Freeman (2006: 421) understands that Cognitive Poetics "links the literary text to the cognitive processes of the human mind, and provides a theoretical cognitive linguistic basis for literary intuition... it shows how they evidence ways in which a literary text bridges the gap between mind and world." In Cognitive Poetics the linguistic description, as in other applications of linguistic theory to literary studies (Leech and Short 1995), examines specific literary phenomena from the perspective of relevant tools developed for linguistic analysis. Among the first, necessarily 
programmatic, studies applying CL insights to literature we have Lakoff and Turner (1989), Tsur (1992), Turner (1996), and Stockwell (2002). Other researchers have worked on the productive symbiosis between well-established areas of literary studies and CL. For example, Emmott (1997) and Fludernik (1993) have developed cognitive narratology, Werth (1999) and Gavins (2005) accommodate insights from CL to text-world theory, and Semino and Culpeper (2002) combine stylistics and CL into a symbiotic discipline called Cognitive Stylistics, which is taken to embrace Cognitive Poetics. As Wójcik-Leese (2010: 20-21) asserts, "a cognitive reading, of course, is simultaneously a new reading, an imaginative apprehension of a text (including its context, the embodied experience of the author and the reader) which derives from detailed linguistic analysis. The emphasis on a linguistic dimension relates cognitive poetics most closely to stylistics."

Cognitive Poetics also features a number of interesting "case studies," i.e. exhaustive applications of specific CL tools to literary analysis. This is the case of Calderón's (2005) study of Seamus Heaney's “Oracle," which makes extensive use of Fauconnier and Turner's Blending Theory, or the study of figurative language in Emily Dickinson's work written by Hamilton (2006), or the broad-ranging application of Conceptual Metaphor Theory constructs to the understanding of the composition processes in Elisabeth Bishop's literary work carried out by Wójcik-Leese (2010). In much the same vein, the present paper discusses plausible cognitive processes of poetic text composition through the study of two of Nabokov's poems. But it differs from other such studies in its highly specific focus on the less than incidental presence of Nabokov's literary motifs, the Doppelgänger, outside his narrative work. Our contention in this respect will be that this literary motif is related to embodied thought as a literary manifestation of the DIVIDED SELF metaphor, which shows abundantly in ordinary language use. At the same time, our own study will add to the state of the art in Conceptual Metaphor Theory in two ways: one, by rescuing a largely neglected metaphorical system from oblivion; the other, by stressing the need to make explicit connections between metaphorical systems and the socio-cultural milieu that underlies them, which, in the case of the poems under scrutiny, has attained a specific literary manifestation in the Doppelgänger motif.

\section{A BRIEF NOTE ON METHODOLOGY}

It should be noted that the problem of conceptual metaphor identification is a controversial one in Cognitive Linguistics. This is so precisely because, in being conceptual, linguists and literary theorists alike can only point to textual evidence of its existence. Exhaustive methods of identification, like the Metaphor Identification Procedure (MIP), developed by the Pragglejaz research group (Steen et al., 2010), are based on the analyst determining the general meaning of the text, the meaning in context of the different lexical units in it, and whether such contextual meaning is related to the basic meaning of the units by some form of similarity. The whole analysis ultimately hinges on the scholar's ability to decide what the 
piece under study actually means, which is itself an open-ended issue in most cases of literary work. In this context, the analytical proposal made in the present paper offers a plausible interpretation of how Nabokov has faced the task of constructing two poems, perhaps only in an intuitive way. It is plausible to the extent that it is consistent with what we know about the poet's life, how this has generally reflected on his writings, and textual clues in the two poems under study. It is also plausible to the extent that this thematic consistency finds evident parallels in the domain of embodied thought, as is the case of the DIVIDED SELF metaphor.

\section{THE 'DIVIDED SELF' METAPHOR}

Lakoff $(1993,1996)$ has argued that we have a folk model of ourselves according to which the person is divided into the Subject, which is related to consciousness and rationality, and the Self, which is the locus of passions and needs. Our western culture wants the Subject to be in control of the Self. For example, in Stevenson's Dr Jekyll and Mr Hyde (Jackson 1981: 114), Mr Hyde, the passionate side of the character, hides in the darkness of the night whilst Dr Jekyll, the rational side of the same character, represses his passion during daytime. There are examples in everyday language that arise from this cultural assumption. This is evidenced by common expressions such as I don't feel myself, I'm not myself today, and That wasn't the real me, among many others.

Lakoff $(1993,1996)$ has made a detailed description of the DIVIDED SELF metaphorical system $^{4}$. Here, we will highlight only those aspects of this metaphor that are particularly productive in the two poems by Nabokov:

- The Divided Person consists of the experiencing consciousness, that is the Subject, and its bodily aspects, that is the Self. So the Subject is hidden inside the Self: I'll show you my real me.

- $\quad$ The Loss of the Self takes place when the Subject loses control over the Self: She lost her mind. The Subject does not guide the Self and this situation is considered negative in our culture.

- The Split Self happens when a person has two incompatible sides: I am quite unstable so I keep going back and forth between my scientific mind and my imaginative one.

- $\quad$ Out to Lunch: The Absent Subject happens when the Subject has no power over the Self because he is crazy, on drugs, and so on. When the Subject is in a normal location (vertical orientation or daily places, such as at home or on the earth), this is associated to control. If that is not the case, then the Subject has not control over the Self: At the beginning he was quite lost but now he is down to earth. 
This metaphor is complex and pervasive in our culture. This is so to such an extent that, as we noted in the introduction, we will argue that this metaphor can even help to structure a literary piece thematically, thus becoming a motif. We will give evidence of this assertion in connection to two poems by Nabokov, entitled Hotel Room and The Execution.

In the case of these poems, we will contend that there are textual clues that lead to a plausible correlation between elements of Nabokov's biography, literary motifs in the poems under scrutiny, and the DIVIDED SELF metaphor. More specifically, we will argue that the expression of the Subject is related to Nabokov's days of the twenties and thirties in the emigrant life provided by the Berlin and Paris refugee centres whilst the Self is related to Nabokov's past days in Russia and his longing for his native land. This is associated with the following comment that Nabokov made to one of his biographers: "The past is my double" (Field 1987: 86).

\section{ON NABOKOV'S BACKGROUND}

In order to better understand Nabokov's feeling about the past that, as has been attested in previous studies (Boyd, 1993), influences his poetry and his use of the DIVIDED SELF metaphor, some notes on his life are in order.

Exile is an important characteristic. It is a predominant feature in the work of such authors as Joyce, Mann, Brecht, Beckett, Ionesco and Nabokov himself. When the Bolsheviks seized power in Russia, Nabokov and his family had to leave their country. In Russia they left their wealthy mansions, their noble family background and their happy easy days. Their new life started in Berlin, where the expatriate Russian community maintained their memories, culture, language and customs in their Russian ghettos. Little by little these emigrants understood that they could not return to their native land because of their political ideas.

As is Nabokov's case, all the Russian expatriates had lost their homes, friends, relatives, and memories upon fleeing from Russia. Field (1967: 87) comments that madness and suicide were a normal occurrence in that atmosphere. Under these circumstances, the young Vladimir Nabokov started his literary career. His early work was written mainly in Russian in those cities where he was forced to live after the 1917 Russian Revolution, such as Berlin and Paris. However, the political and military events in Europe with the German National-Socialist Party as well as his marrying a Jewish lady made him think of going to the United States. Right after Nabokov arrived in the States he began his "love affair with the English language" (Bradbury, 1985: 153). Nabokov is best known for the writing of novels, but his short stories and poetry are also an important part of his literary work.

The first poetry he wrote was in Russian and later he rewrote it brilliantly in English, although he always thought that switching from the Russian language into English was "painful -like learning anew to handle things after losing seven or eight fingers in an explosion" (Nabokov, 1990: 54). 
In the United States he acquired fame with his novel "Lolita" and later he translated most of his Russian literary work into English. This is how his English speaking readers became acquainted with his lyric work.

\section{THE 'DIVIDED SELF' METAPHOR AS A LITERARY MOTIF}

The DIVIDED SELF metaphor manifests itself not only in everyday thought and language use, as amply exemplified by Lakoff $(1993,1996)$, but also as a literary motif. The literary motif has been called double, alter ego, or Doppelgänger. There is a number of scholars who have studied the motif of the double and the mirror in Nabokov's literary work, among them Levin (1988), Kanevskaya (2003), Zaitseva (2004), Barreras (2005), and Kressova (2011). This motif is concerned with the characterization in a narrative text. The double and his model are of the same gender and both of them share different characteristics. The Doppelgänger is generally shaped as a shadow or mirror image that serves to create two symmetrical plots that run parallel to each other based on the two parallel characters. Furthermore, the Doppelgänger is an artistic principle, which may be used to examine and portray psychological, aesthetic and formal artistic problems, such as the relationship between the author and what he is writing (Clancy, 1984: 59). In addition to this, Jung asserts: "The shadow cast by the conscious mind of the individual contains the hidden, repressed, and unfavorable (or nefarious) aspects of the personality" (Jung 1968: 110). This remark is largely in line with Lakoff's (1996) argument about the person as being culturally divided into the Subject (consciousness and rationality) and the Self (passions and needs). What Lakoff adds is the important observation that the Subject-Self aspects of people are often exploited metaphorically thus giving rise to the DIVIDED SELF metaphorical system.

It is interesting to note that, although Nabokov is known to have remarked that "The Doppelgänger subject is a frightful bore" (1990: 83), the writer himself has actually made non-occasional use of false doubles in his narratives. However, Nabokov stresses the psychological features of the motif instead of the physical ones. The result is that one of his characters feels that he has a double, which is not perceived as such by the rest of the characters. This is one of the most relevant features of the plot of novels such as Despair (from Nabokov's Russian period) and Lolita (from his later American period), whose development is much based on this literary motif. Moreover, when both the protagonist and his double are talking together there is no other character with them so that nobody else is able to see their similarity. In this way, the interaction between the protagonist and his double embodies all the relevant characteristics of the Doppelgänger motif, to which Nabokov adds irony and parody. For example, in Lolita the protagonist, Humbert Humbert (note the double name) shoots his double Clare Quilty (note the play on words here too), who takes too long to die even after being shot over and over again. The ironical effect is based on the painstaking difficulty involved in the protagonists repeated attempts to murder his double. 
We find other examples of this motif in some of Nabokov's narrative pieces. This is the case of Floyd and Lloyd in the short story "Scenes from the Life of a Double Monster," or of a number of characters in the following novels: Albinus and Rex in Laughter in the Dark, Cincinnatus and Pierre in Invitation to a Beheading, Kinbote and Shade in Pale Fire, Van and Ada in $A d a$, and Hermann and Felix in Despair. In these narratives the motif is explicitly incarnated in the protagonists. In the following sections we will argue that the same motif underlies, in a more subtle way and to different degrees, two of Nabokov's poems, Hotel Room and The Execution. In both, Nabokov depicts himself as divided into his rational and emotional selves, which he largely treats in terms of the DIVIDED SELF metaphor. In other words, what we find is the metaphorical exploitation of the literary motif that is attested in much of his narrative work.

\section{HOTEL ROOM AND THE EXECUTION}

These two poems were first written in Russian and then were translated into English by Nabokov himself. Hotel Room was written in Sebastopol in 1919. The Nabokov family had arrived there after leaving Livadia as the Red Army was advancing quickly through Crimea. Under these circumstances, their fleeing was distressing. Moreover, Nabokov's brother and one of his sisters became sick on their way to Sebastopol. As Nabokov's father was a cabinet minister of the Regional Government, the family was lodged in the Metropole hotel (Boyd, 1993, p. 159).

The Execution was written in Berlin in 1927. By that time Nabokov had published some short stories such as "Details of a Sunset" (1924) or "A Letter that Never Reached Russia" (1925), and a novel, Mary (1926). His literary works were getting well known in the Russian émigré literary magazines such as "Rul" (Barreras, 2003: 25).

Nabokov translated both poems into English as well as other poems first written in Russian. Later he published them with others written in English for the first time in the book entitled "Poems and Problems" (1970).

\subsection{Hotel Room}

This is the first of the two poems:

\section{Hotel Room}

Not quite a bed, not quite a bench, Wallpaper: a grim yellow A pair of chairs. A squinty looking-glass. We enter-my shadow and I.

We open with a vibrant sound the window:

The light's reflection slides down to the ground. 
The night is breathless. Distant dogs

With varied barks fracture the stillness.

Stirless I stand there at the window,

And in the black bowl of the sky

Glows like a golden drop of honey

The mellow moon

As is evident, the first and third lines of the first quatrain are constructed on the basis of symmetrically arranged parallel structures. Such symmetry is signaled by the division of each line into two hemistichs through a caesura. Lines two and four also feature a caesura each, but there is not parallelism between the structures of the resulting hemistichs. This peculiar arrangement creates a feeling of duality that finds a conceptual or thematic counterpart in the fourth line, where the poet talks about himself as accompanied by his own shadow, which is personified and thus endowed with human-like features in the poem. These lines are additionally characterized by phonic, syntactic and structural pointers to duality, which helps to introduce the DIVIDED SELF metaphor in the fourth line ("We enter -my shadow and I" 1.4). Moreover, the first quatrain contains two other images that are suggestive of duality: "pair of chairs" (1.3), and "looking glass" (1.3) (because of the reflection). The environment provides a match of the poet's feelings of internal dividedness.

Lakoff (1993: 94) asserts that culturally the ideal situation is one in which the Subject is in control of the Self. However, this ideal situation is not always the case as is reflected in expressions like I'm not myself today or I'm scattered, which, by conveying lack of control, have negative connotations. In Nabokov's poem the situation depicted in the first four lines is similarly negative. Here the shadow is the projection of the Subject's feelings that he cannot control (his longing for his Russian past, the anguish of exile). This is the Self. In Western culture darkness carries a connotation of fear and mystery that is not desirable. The Self is tinged with such a connotation, which is consistent with, and reinforced by, the general atmosphere suggested by the use of "grim yellow" (1.2), "not quite" (1.1), and "shadow" (1.4).

The second quatrain pursues with the DIVIDED SELF explicitly introduced at the end of the first quatrain ("We open with a vibrant sound the window"; 1.5). The metaphor HIDDEN IS IN and VISIBLE IS OUT (Lakoff, 1993, p. 100) (e.g. The truth came out; Keep your feelings in) is exploited in the line "We open with a vibrant sound the window" (1.5), which may be interpreted in the sense that both Subject and Self are shut away in the house and they open the window to have access to the world. Then, a number of images follow, all of them consonant with the feelings of gloom that pervade the previous lines. One of the images consists in the reflection of light "sliding" down to the ground. This image suggests that this is still the world of the Self. Moreover, the experiential correlation between sadness and down positions plays an additional role here (as Lakoff \& Johnson, 1980, note, drooping postures, which involve this position, are signals of depression and sadness). We envisage the poet as being driven by his feeling of distress because of his escape from the Russian 
revolution and his new life as an immigrant longing for his native land. Moreover, Lakoff and Johnson (1999, p. 269) characterize the Self as "past states and actions in the world."

A second image is the "breathless night" (1.7). The adjective breathless suggests stillness and, at the same time, feelings of anguish (as when someone feels unable to even breathe). It is dark and there is not much noise. Only the "vibrant sound" (1.5) produced when opening the window and the noise of dogs barking disrupt the "stillness" (1.8) of the night.

On a more general level of analysis, we note that the first quatrain underlines the idea of "we," while the second quatrain, which starts with this idea, then gives way to the idea of "I," which stands out in the third quatrain, as we will see later. The first quatrain is framed inside of a room; outdoors is the main topic in the third quatrain. This transition is prefigured by the mention of the two silence-breaking factors, i.e. the "vibrant sound" (1.5) and the "distant dogs with varied barks" (1.7-8), which the poet becomes aware of as he gets in touch with the outer world when opening the window of his closed room in the first quatrain.

In the third quatrain we witness how the Subject regains control of the Self. Evidence of this is the poet referring to himself as "I" instead of "we" in "Stirless I stand there at the window" (1.9). The use of "stand" invokes verticality and the associated conceptual connection provided by the metaphor SELF-CONTROL IS UP (Lakoff, 1993: 107). Here we have a vertical position image. This situation is also connected to the metaphor RATIONAL IS UP since the Subject (the rational side) holds control over the Self (associated with feelings and the past) as in Mary couldn't rise above her emotions. Therefore, we come across positive connotations with words such as "glows" (1.11), "golden" (1.11), and "mellow" (1.12). There is a vertical position associated with exerting control. Finally, the moon is bright in the dark sky. It sheds light. This has to do with the metaphor LIGHT IS KNOWLEDGE, which is based on the physiological act of seeing, which allows us to know. This is a positive action, which could explain why the poet uses the positive adjective "mellow" in "the mellow moon" (1.12). The Subject is in control of the Self. The metaphor HAPPY IS UP also plays a role here. In general, an upper position is a good position in terms of providing people with protection (for example from predators), and a vantage point (for instance by allowing to see the enemy, to have a broader view of a landscape or a scene, etc.). For this reason, positive feelings, such as happiness, or positive ideas are figuratively considered to be "up" (cf. the common expression: "When I'm feeling up, nothing gets me down"). This analysis is coherent with the observation that there does not seem to be any anguish in the last lines of the poem.

\subsection{The Execution}

Unlike Hotel Room, the following poem starts with an explicit reference to the poet himself ("I"), which is held active until the last quatrain, where the situation is unbalanced through the sudden explicitation of the DIVIDED SELF metaphor. There are hints elsewhere in the poem that the poet is divided up between the real life he has to face, which falls within the domain of his rational self, and the yearnings of his heart, which is his emotional self (e.g. "my bed 
starts drifting into Russia"; 1.2). The poet is well aware that, if he returned to Russia, where his heart wishes he could be, he would have to face a fatal destiny. The thematic structure of the whole poem, therefore, hinges upon this subtly conveyed division. Thus, the first quatrain contains an implicit allusion to the DIVIDED SELF metaphor based on the poet watching himself in a dream over which he has no conscious control. Then, in the second and third quatrains, as the poet wakes from his dream, there is a reintegration of the divided poet into one single self where the (irrational) self dominates over the (rational) subject. The fourth quatrain involves a shift back from irrational fear to rational control of the subject over the self, where the poet realizes once more that, whatever the longings of his heart, his exile places him in a protected position. It is only then, when, in the fifth quatrain, the realization that he is divided between heart and reason is made fully explicit. Let us now address each quatrain in more detail.

\section{The Execution}

On certain nights as soon as I lie down my bed starts drifting into Russia, and presently I'm led to a ravine, to a ravine led to be killed.

I wake - and in the darkness, from a chair where watch and matches lie, into my eyes, like a gun's steadfast muzzle, the glowing dial stares.

With both hands shielding breast and necknow any instant it will blast! I dare not turn my gaze away from that disk of full fire.

The watch's ticking comes in contact with frozen consciousness; the fortunate protection of my exile I repossess.

But how you would have wished, my heart, that thus it all had really been:

Russia, the stars, the night of execution and full of racemosas the ravine!

In the first quatrain of this poem the Subject is presented as belonging to the present and the Self to the past: "as soon as I lie down/ my bed starts drifting into Russia" (1.1-2). Nabokov's Self is associated with his past in Russia, instead of his present, with his exile in Berlin. This is consonant with the use of the metaphor SELF CONTROL IS UP. When the subject lies down he does not possess that self-control (Peña, 2003: 251), as revealed by everyday expressions like fall asleep, be down, etc. This idea of lack of control is reinforced by the use of the verb "drift" (1.2), which involves slow motion, especially resulting from external 
forces, with no control over direction. One knows that the Subject normally controls the Self when it is in a normal position, which is the upright orientation (for example, He has got his feet on the ground). However, this is not the case in this quatrain.

Moreover, we understand that the Self is also associated with passions and emotions. In this respect, we find in the poem an anguishing image: "I'm led to a ravine,/ to a ravine led to be killed" (1.3-4). It is interesting to note the 'captivity' image implied by a ravine, which is a deep narrow cleft. This carries a negative connotation since Nabokov would not find this place easy to escape from. We have to take into account that Nabokov was a White Russian and he was not allowed to come back to his native land. If he did, he could be punished with the death penalty. The Self, the place where emotions and past history are figuratively located, dominates the events depicted in this quatrain, which are tinged with anguish.

The second quatrain marks the start of a situation where the Subject gradually regains control over the self: "I wake" (1.5). It is still dark. However, there is also an image related to light, connected to the mention of "matches" (1.6), as they can illumine, and the "glowing dial" (1.8). This brings the metaphor LIGHT IS KNOWLEDGE into the picture. This metaphor is conceptually associated with the Subject as the locus of consciousness and knowledge. In addition to this, the presence of the Subject is reinforced with the symbol of time in the shape of a dial and a watch. This refers to chronological time and, consequently, to the Subject's realm. As noted above, as attention is shifted to the watch and the matches the Subject starts having control over the situations. However, the feelings of impeding danger still loom large in the poet's mind: the dial of the watch reminds him of the barrel of a gun: "like a gun's steadfast muzzle, the glowing dial stares" (1.7-8). Although Subject and Self have been reintegrated the poet still allows the emotional aspects of fear dominate his experience.

The third quatrain follows up on the second. There is terror: "With both hands shielding breast and neck/ now any instant it will blast" (1.9-10). The anguish of the Self stems from the fear that in the new USSR his life may finish at any moment. The dial of the chronological time of the Subject's realm becomes "a disk full of fire" (1.12), which is a metaphor for 'gun.' The Subject is still in a situation of lack of control of the Self.

It is in the fourth quatrain where the Subject finally regains control of the Self ("the fortunate protection of my exile I repossess"; 1.15-16). This is consistent with the author making reference to the "watch" (1.6), which reminds the reader of the objectivity of chronological time. It also reminds the reader of the present time, that is, exile, where the Subject keeps control of his emotions. Such control is also marked off by the reference to the "frozen consciousness" (1.14). This expression is a realization of the experiential metaphor that correlates emotions with heat and the lack of emotions with coldness (e.g. ANGRY IS HOT/CALM OR PASSIONLESS IS COLD; cf. Lakoff, 1987). In this case the ticking sound of the watch -objective, neutral, "out there"- is made to match the Subject's figurative frozenness, which suggests lack of concern or indifference. The Subject taking power over the Self is felt as positive; this is underscored by the poet when referring to the protection provided by his 
exile as a "fortunate" right that he has regained ("I repossess"; 1.16). The Subject, who is tied to the present time, lives safely in exile. The heaviest thoughts of people murdered in Russia and the feeling of terror about the new country called the USSR have led the Self into an uneasy world, inhabited by the passions of terror and anguish. However, the Subject can control those passions and feel safe in exile.

Finally, in the fifth quatrain the reader detects the great nostalgia in the poet for his lost country, Russia. He addresses himself as "my heart" (1.17). The Subject addresses his own Self, which reminisces of "Russia" (1.19), "the stars" (1.19), but also, in marked contrast, brings to memory his anguish for "the night of execution" (1.19) and "the ravine" (1.20). The Subject loses power over the Self when remembering his lost country and thinking about the White Russians put to death because of their ideas. There is a feeling of longing mixed with anguish, which is invoked by the ravine. However, the ravine is full of racemosas, which, for Nabokov, are axiologically positive flowers linked to his nostalgia over Russia (cf. Toker 1989: 92). Consequently, the ravine is not the prototypical one. Although it is still a deep narrow valley with steep slides, there is something positive, the racemosas (a kind of bird cherry, used in descriptions by Nabokov in novels such as Mary, Ada or Ardor, Glory, or Speak, Memory).

The fifth quatrain is based on opposites. The first one is marked by the expressions "you would have wished" (1.17) and "it all had really been" (1.18), that is, unreality versus reality. The second one is "Russia, the stars" (1.19) versus "the night of execution" (1.19). Russia and the stars are associated to the light whilst night and execution are associated to darkness. There are contrary images, memories and, consequently, feelings. Finally, the use of these opposing images lead the reader up to the final mention of the non-prototypical ravine, which is full of racemosas. The Subject sees himself as if he had been captured, which is a desperate situation; by contrast, the Self feels nostalgia, which is why the situation is not totally anguishing.

As with many other Nabokov's poems, the memories, the past experience, the longing for his lost country lead to an unbalanced situation, which surfaces in the two poems discussed above, to different degrees, through the thematic and structural use of the DIVIDED SELF metaphor.

\section{CONCLUSIONS}

This paper has approached two of Nabokov's poems from the perspective of embodied realism in Cognitive Linguistics. Our main goal was to explain Nabokov's use of the DIVIDED SELF metaphor to structure thematically two of his poems. In the first poem, Hotel Room, we have found a number of parallelisms and dualities that reflect the use of the DIVIDED SELF metaphor. We understand that the shadow is the projection of the author's feelings of anguish and longing for his Russian past, which corresponds to the Self. At the beginning of The 
Hotel Room the Subject and the Self are completely divided. However, the Subject gradually regains control over the Self. This materializes in the step-by-step introduction of examples of the SELF-CONTROL IS UP and RATIONAL IS UP metaphors and the metaphor LIGHT IS KNOWLEDGE, which bring with them a number of positive connotations grounded in experience. Eventually, the Subject becomes in full control of the Self, which is good from the point of view of western culture.

In The Execution there are examples of the DIVIDED SELF metaphor in which the Subject, related to Nabokov's present day at that time, belongs to the present. By contrast, the Self, related to his days in Russia and his longing for his native country, belongs to the past. Again the Subject starts taking control over the Self. This is connected to the passage of time, as reflected in the use of symbols pertaining to the realm of chronological time (a watch with its spherical dial) in combination with the use of the LIGHT IS KNOWLEDGE metaphor, which is associated with consciousness and knowledge, the Subject's realm, and with the use of PASSIONLESS IS COLD metaphor. The notion of "frozen" (1.14) is associated with coldness and the Subject's indifference and emotional detachment. At the end, we appreciate a great nostalgia for his lost country. The Subject loses control over the Self only when remembering his native land.

Wójcik-Leese (2010: 84) has asserted that "a cognitive reading of a literary text appreciates the cognitive processes that motivate them." The analysis of Hotel Room and The Execution has revealed the challenges of the poet's youth, his feelings of loss for his native country, his life in exile, his anguish and longing for his past. He sometimes overcomes these feelings, as is shown in Hotel Room, but not in The Execution. A cognitive reading of both poems has allowed us to appreciate Nabokov's use of the DIVIDED SELF metaphor as a literary motif. This is portrayed in the content and topics of his two poems as well as in the way he uses language to address his innermost feelings about such challenging times.

\section{NOTES}

1. The research on which this paper is based has received financial support from the Spanish Ministry of Science and Innovation, grant number FFI2013-43593-P.

2. The notion of embodiment has an antecedent, as noted by Dirven and Ruiz de Mendoza (2010: 37 ), in the work of the phenomenologist Merleau-Ponty who points to the relationship between consciousness and perception, especially spatial experience, which in Cognitive Linguistics is crucial to understand the categorization of world phenomena.

3. Metaphor also has neurological grounding. As Tsen and Bergen (2005) explain, the part of the motor cortex of the brain connected to the hands is active when the hands are employed, talked about and also used as the source domain of a metaphor. Consequently, the brain uses the same circuitry to process both "our hands touched" and "you touch my heart," that is, it conflates real and conceptual information.

4. For an overview of the linguistic and communicative implications of this metaphor, see Ruiz de Mendoza (1998) and Ruiz de Mendoza and Galera (2014: 79). 


\section{REFERENCES}

Bara, B. \& Bucciarelli, M. (2005). Proceedings of the Cognitive Science Society. Mahwah, NJ: Erlbaum.

Barreras Gómez, $\mathrm{M}^{\mathrm{a}}$ A. (2003). El juego intelectual. Ironía y textualidad en las narraciones breves de Vladimir Nabokov. Logroño: Universidad de La Rioja. Servicios de publicaciones.

Bergen, K. B. (2005). Mental simulation in literal and figurative language understanding. In S. Coulson \& B. Lewandowska-Tomaszczk (Eds.), The Literal and Nonliteral in Language and Thought (pp. 255-280). Frankfurt: Peter Lang.

Bobrow, J. \& Collins, A. (Eds.). Representation and Understanding: Studies in Cognitive Science. New York: Academic Press.

Boyd, B. (1993). Vladimir Nabokov. The Russian Years. Londres: Vintage Edition.

Bradbury, M. \& Ro. S. (1985). Contemporary American Fiction. London: Edward Arnold.

Calderón Quindos, $\mathrm{M}^{\mathrm{a}} \mathrm{T}$. (2005). Blending as a theoretical tool for poetic analysis: Presenting an integracional methodology. Annual Review of Cognitive Linguistics, 3(1), 269-299.

Casasanto, D. \& Boroditsky, L. (2008). Time in the mind: Using space to think about time. Cognition, 106, 579-593.

Clancy. L. (1984). The novels of Vladimir Nabokov. London: Macmillan.

Dirven, R. \& Ruiz de Mendoza, F. (2010). Looking back at 30 years of Cognitive Linguistics. In E. Tabakowska, M. Choinski \& L. Wiraszka (Eds.), Cognitive Linguistics in Action (pp. 13-70). Berlin: De Gruyter Mouton.

Emmott, C. (1997). Narrative comprehension: A discourse perspective. Oxford: Oxford University Press.

Field, A. (1967). Nabokov: His Life in Art. London: Hodder and Stoughton.

Field, A. (1987). The Life and Art of Vladimir Nabokov. London: Macdonald Queen Anne Press.

Fludernik, M. (1993). The Fictions of Language and the Languages of Fiction: The Linguistic Representation of Speech and Consciousness. London: Routledge.

Freeman, M. H. (2006). The fall of the wall between literary studies and linguistics: Cognitive Poetics. In G. Kristiansen, M. Achard, R. Dirven \& F. J. Ruiz de Mendoza (Eds.), Cognitive Linguistics: Current Applications and Future Perspectives. (pp. 403-428). Berlin: Mouton de Gruyter.

Gavins, J. (2005). (Re)thinking modality: A text-world perspective. Journal of literary semantics, 34(2), 79-93.

Gibbs R. (2011). Evaluating conceptual metaphor theory. Discourse Processes 48(8), 529-562.

Haiman, J. (2008). In defence of iconicity. Cognitive Linguistics, 19, 59-66.

Hamilton, C. (2006). A cognitive rhetoric of poetry and Emily Dickinson. Language and Literature, $15,381-393$.

Jackson, R. (1981). Fantasy: The Literature of Subversion. London: Methuen.

Johnson, M. (1987). The Body in the Mind. Chicago: The University of Chicago Press.

Jung, G. (1968). Man and his Symbols. New York: Dell/Laurel.

Kanevskaya, M. (2003). The semiotic validity of the mirror image in Nabokov's Despair. In G. Shapiro (Ed.), Nabokov at Cornell. (pp. 20-30). Ithaca and London: Cornell University Press.

Kövecses, Z. (2000). Metaphor and Emotion. New York and Cambridge: Cambridge University Press.

Kövecses, Z. (2011). Methodological issues in conceptual metaphor theory. In S. Handl \& H. Schmid (Eds.), Windows to the Mind: Metaphor, Metonymy and Conceptual Blending (pp. 23-40). Berlin: Mouton de Gruyter.

Kressova, N. (2011). Cercanos y distantes: Jorge Luis Borges y Vladimir Nabokov: un estudio comparado. Saarbrücken: Editorial Académica Española.

Lakoff, G. (1987). Women, Fire and Dangerous Things. Chicago: The University of Chicago Press.

Lakoff, G. (1993). The internal structure of the Self. In U. Neisser \& D. A. Jopling (Eds.), The Conceptual Self in Context, Culture, Experience and Self Understanding (pp. 92-114). Cambridge: Cambridge University Press.

Lakoff, G. (1996). Sorry, I'm not myself today: The metaphor system for conceptualizing the Self. In G. Fauconnier \& E. Sweetser (Eds.), Spaces, worlds, and grammar (pp. 91-123). Chicago: University of Chicago Press.

Lakoff, G. \& Johnson, M. (1980). Metaphors We Live by. Chicago: The University of Chicago Press.

(C) Servicio de Publicaciones. Universidad de Murcia. All rights reserved. IJES, vol. 15 (1), 2015, pp. 97-113 Print ISSN: 1578-7044; Online ISSN: 1989-6131 
Lakoff, G. \& Johnson, M. (1999). Philosophy in the Flesh. New York: Basic Books.

Lakoff, G. \& Johnson, M. (2002). Why Cognitive Linguistics requires embodied realism. Cognitive Linguistics, 13(3), 245-263.

Lakoff, G. \& Turner, M. (1989). More than Cool Reason: A Field Guide to Poetic Metaphor. Chicago: University of Chicago press.

Langacker, R. W. (1987). Foundations of Cognitive Grammar. Vol. 1: Theoretical prerequisites. Stanford, CA: Stanford University Press.

Langacker, R. W. (1999). Grammar and conceptualization. Berlin / New York: Mouton de Gruyter.

Leech, N.G. \& Short, M. H. (1995). A Style in Fiction. A Linguistic Introduction to English Fictional Prose. London: Longman.

Levin, Y. (1988). Espejo. Semiótica del espejo. Los procedimientos de los sistemas de signos. Tartu: Publicaciones de la universidad de Tartu.

Nabokov, V. (1970). Poems and Problems. New York: McGraw-Hill Book Company

Nabovok, V. (1990). Strong Opinions. New York: McGraw-Hill Book Company.

Neisser, U. \& Jopling D. A. (1997). The Conceptual Self in Context, Culture, Experience and Self Understanding. Cambridge: Cambridge University Press.

Peña Cervel, S. (2003). Topology and Cognition. München: Lincom Europa.

Ruiz de Mendoza, F. (1998). On the nature of blending as a cognitive phenomenon. Journal of Pragmatics, 30, 259-274.

Ruiz de Mendoza, F. \& Pérez, L. (2011). The contemporary theory of metaphor: Myths, developments and challenges. Metaphor and Symbol, 26(3), 161-185.

Ruiz de Mendoza, F. \& Galera, A. (2014). Cognitive Modeling. A Linguistic Perspective. Amsterdam: John Benjamins Publishing Company.

Rumelhart, D. E. (1975). Notes on a schema for stories. In Bobrow, J. \& Collins, A. (Eds.), Representation and Understanding: Studies in Cognitive Science (pp. 211-236). New York: Academic Press.

Rumelhart, D. E. (1980). Schemata: The building blocks of cognition. In R. Spiro, B. Bruce \& W. Brewer (Eds.), Theoretical Issues in Reading Comprehension: Perspectives from Cognitive Psychology, Linguistics, Artificial Intelligence, and Education (pp. 33-58). Hillsdale, NJ: Erlbaum.

Semino, E. \& Culpeper J. (Eds.) (2002). Cognitive Stylistics: Language and Cognition in Text Analysis. Amsterdam: Benjamins.

Steen, G. J., Dorst, A. G., Herrmann, J. B., Kaal, A., Krennmayr, T. \& Pasma, T. (2010). A Method for Linguistic Metaphor Identification. Amsterdam: Benjamins.

Steiner, G. (1970). Extraterritorial: Papers on Literature and Language Revolution. New Cork: Atheneum.

Stockwell, M. (2002). Cognitive Poetics: An Introduction. London: Routledge.

Talmy, L. (2000). Toward a Cognitive Semantics. Cambridge, MA: MIT Press.

Thorndyke, P. (1977). Cognitive structures in comprehension and memory of narrative discourse. Cognitive Psychology, 9, 77-110.

Toker, Leona. (1989). Nabokov. The Mystery of Literary Structures. Ithaca, NY: Cornell University Press.

Tseng, M. J. \& Bergen, B. K. (2005). Lexical processing drives motor simulation. In B. Bara, L. Barsalou \& M. Bucciarelli (Eds.), Proceedings of the Cognitive Science Society (pp. 22062211). Mahwah, NJ: Erlbaum.

Tsur, R. (1992). Toward a Theory of Cognitive Poetics. Amsterdam: North Holland.

Tsur, R. (2002). Some aspects of Cognitive Poetics. In E. Semino \& J. Culpeper (Eds.), Cognitive Stylistics: Language and Cognition in Text Analysis (pp. 279-318). Amsterdam: Benjamins.

Turner, M. (1996). The Literary Mind: The Origin of Thought and Language. New York: Oxford University Press.

Werth, P. (1999). Text Worlds: Representing Conceptual Space in Discourse. Harlow: Longman.

Wójcik-Leese, E. (2010). Cognitive Poetic Readings in Elizabeth Bishop. Portrait of a Mind Thinking. Berlin: De Gruyter Mouton.

Zaitseva, Yu. (2004). Motiv zerkala v judozhestvennoi sisteme V. Nabokova (na materiale russkoi prozy), Avtoreferat. Perm. 